\title{
Factors Affecting Decomposition Rates of Chironomid (Diptera) Pupal Exuviae
}

\author{
Rathi G. Kavanaugh ${ }^{1,3}$, Alexander T. Egan ${ }^{2, *}$ and Leonard C. Ferrington, Jr. ${ }^{2,3}$ \\ ${ }^{1}$ Environmental Health \& Safety, University of Cincinnati, Edwards II 2310, Cincinnati, OH 45221 USA \\ (Current address).E-mail: kavanari@ucmail.uc.edu \\ ${ }^{2}$ Department of Entomology, University of Minnesota, 1980 Folwell Ave., St. Paul, MN 55108 USA. \\ E-mail: egan0059@umn.edu (ATE),ferri016@umn.edu (LCF) \\ ${ }^{3}$ Kansas Biological Survey and Department of Entomology, University of Kansas, 2291 Irving Hill Road, \\ Lawrence, KS 66046 USA \\ * Corresponding author
}

\begin{abstract}
Collections of floating chironomid pupal exuviae are used to monitor water quality and assess ecological conditions. Factors controlling exuviae sinking rates are not well known, although they should have an effect on conclusions that can be drawn from collections. The current study was conducted to determine the rate of sinking under controlled laboratory conditions using water from three streams with different nutrient levels. Sinking rates ranged from less than a day to seven days, depending on microbial activity, nutrient concentrations, temperature and turbulence. Results also varied by genus, with pupal exuviae of Chironomus riparius, Diamesa nivoriunda, Orthocladius (Euorthocladius) thienemanni and Eukiefferiella sp. used in experiments. Four species of bacteria and eight genera of fungi colonized and metabolized exuviae, with bacteria dominant early and fungi dominant later in the decomposition process. Decomposition was faster in lightly chitinized abdominal conjunctive areas, which resulted in exuviae breaking apart and sinking. Examination of untreated, dewaxed and dewaxed-deproteinized exuviae indicated that untreated exuviae sank faster. Waxes appeared important for colonization and initial microbial metabolization was delayed when waxes were removed. Results confirm the importance of biological degradation of exuviae in determining floatation times. We predict that streams and other waterbodies with high dissolved nutrients will result in rapidly sinking exuviae, while exuviae in low nutrient waterbodies will float longer.
\end{abstract}

\section{Introduction}

Chitin, an inert and insoluble polysaccharide found in insect cuticle, is among the most abundant naturally occurring organic compounds on Earth (Nation 2008). Pupal exuviae of Chironomidae are primarily chitin-protein complexes with a waxy coating (Anderson 1979, Nation 2008). Chitino- clastic microbes are common in both aerobic and anaerobic aquatic environments (e.g., Warner and Randles 1977, Bye and Charnley 2008). Therefore, exuviae should be colonized by chitinoclastic bacteria and fungi (Tracy and Valletyne 1968, Dick 1970). Variability in colonization and growth of chitinoclastic bacteria and fungi has potential to change decomposition rates of exuviae.

Collections of chironomid pupal exuviae have been increasingly used to monitor water quality, assess ecological communities, and classify trophic status of waterbodies in both lotic and lentic systems (Coffman 1973, Raunio and Muotka 2005, Raunio et al. 2010, Bouchard and Ferrington 2011). Exuviae are generally easy to locate and efficient to collect, and species occupying many microhabitats can be detected (Wilson and Ruse 2005). Keys in recent decades have made exuviae identification to genus relatively easy (Langton 1991, Ferrington et al. 2008) and species-level keys are available for many genera.

A methodological variable in studies using collections of pupal exuviae is the length of time exuviae remain floating on the surface of the water (Coffman 1973, Wilson and Ruse 2005). A preliminary study on lentic exuviae suggested that sinking generally occurred within 2-10 days, depending on temperature, microbial activity and mechanical disruption (Coffman 1973). However, time necessary for breakdown appeared strongly influenced by the degree of chitinization, so that certain species may be under- or overrepresented in samples depending upon the time interval between population emergence and sampling events.

Although sinking of exuviae has been tentatively linked to microbial activity, to our knowledge, this direct association has not been studied. The present study investigated factors that affect the sinking of exuviae, along with the role of bacteria and fungi in the metabolism and break down of exuviae. Objectives were to: 1) examine factors 
that may affect the sinking of exuviae, including temperature, nutrients, microbial activity and mechanical disruption; 2) isolate and identify microorganisms metabolizing chironomid exuviae; 3) document the succession of microorganisms on exuviae; and 4) determine the effect of dewaxing and deproteinization on exuviae sinking.

\section{Materials and Methods}

\section{Collection of Exuviae and Water Samples}

Collections occurred between May 1984 and April 1986. Exuviae of Chironomus riparius Meigen were collected in spring and summer from Mill Creek, Johnson County, Kansas (T13S, R23E, Sec. 13). Mill Creek received sewage effluent, with a high concentration of nutrients compared to the other study sites. Exuviae of Diamesa nivoriunda (Fitch), Orthocladius (Euorthocladius) thienemanni Kieffer and Eukiefferiella sp. were collected in winter and spring from Deer Creek, Douglas County, Kansas (T12S, R18E, Sec. 31). Deer Creek was relatively unimpacted, clear, and slow-flowing.

Recently shed pupal exuviae were collected from the stream surface soon after emergence of adults. Exuviae were handpicked using forceps, initially from within a $16^{\prime} \times 3$ ' emergence channel constructed of a plywood frame and sides resting on the stream bottom, and a net on the upstream and downstream ends. Once the upstream net was in place, the channel sides allowed an area of streambottom substrates to be "enclosed" for a known period of time, providing access to newly shed exuviae. The downstream net was subsequently affixed after allowing enough time for older exuviae to drift through the channel. Later in the season, low water levels required hand picking exuviae without use of the channel. During late-season collections, newly shed exuviae were determined based on lack of water in the cephalothorax, complete and unbroken specimens, and no visible fungal or bacterial growth.

Water samples for experiments and microbial analyses were collected during the same visit from the streams noted above, along with Mud Creek, Douglas County (T12S, R20E, Sec. 7). Mud Creek was turbid due to channelization, fast flowing, lacked riparian vegetation, and received run-off from surrounding agricultural fields. Sterile flasks wrapped in aluminum foil were used to collect water samples for microbial analyses. Flasks were unwrapped just before sampling, plugs were removed and flasks immediately dipped to collect surface water to a depth of $1 / 2$ inch, then resealed for transport. No more than 60 minutes passed from collection to plating for microbial analyses. Water samples for chemical analyses and experiments were collected in 1-liter bottles washed in concentrated sulfuric acid and rinsed with distilled water before sampling. Water and exuviae were transported to the laboratory in a cooler at about $10^{\circ} \mathrm{C}$. Unless noted below, all experiments were conducted at room temperature $\left(20^{\circ} \mathrm{C}\right)$.

\section{Experiments}

\section{1) Factors affecting exuviae sinking}

a) Establishing baseline data: Exuviae of Diamesa nivoriunda, Orthocladius (Euorthocladius) thienemanni and Eukiefferiella collected from Deer Creek were held in a single flask containing stream water. The time required for all exuviae to sink was recorded. This experiment was repeated three times.

b) Nutrients and mechanical shaking: Ten exuviae each of D. nivoriunda, O. thienemanni and Eukiefferiella collected in Deer Creek were separately transferred to three flasks. A nutrient solution (\#1) of $0.4 \mathrm{~g}\left(\mathrm{NH}_{4}\right)_{2} \mathrm{SO}_{4}$ and $0.1 \mathrm{~g}$ of $\mathrm{K}_{2} \mathrm{H}_{2} \mathrm{PO}_{4}$ was added to $20 \mathrm{~mL}$ of Deer Creek water. Two $\mathrm{mL}$ of the solution was added to each of two flasks, one kept on a shaker and the other on a table with occasional shaking by hand to simulate the light turbulence of natural conditions. The third flask was also occasionally shaken by hand but had no nutrient solution added. The time required for all exuviae to sink was recorded. This experiment was repeated twice.

c) Nitrate-nitrogen vs. ammonia-nitrogen: A second nutrient solution (\#2) was prepared using 0.4 $\mathrm{g} \mathrm{NaNO}_{3}$ and $0.1 \mathrm{~g} \mathrm{~K}_{2} \mathrm{H}_{2} \mathrm{PO}_{4}$ in $20 \mathrm{~mL}$ of distilled water. Both nutrient solution concentrations were purposely above ambient stream conditions to ensure any response would be measurable. Ten exuviae of D. nivoriunda, O. thienemanni and Eukiefferiella were transferred to 8 flasks containing $20 \mathrm{~mL}$ Deer Creek water. Four flasks had $2 \mathrm{~mL}$ of nutrient solution \#1 added and four flasks had 2 $\mathrm{mL}$ of nutrient solution \#2 added. For each treatment, two flasks were kept on a shaker and the other two on a table with occasional hand shaking. The percentage of exuviae sinking in three days was recorded. This experiment was repeated twice.

d) Temperature, microbial activity and mechanical shaking: Ten Chironomus riparius exuviae were transferred to each of three flasks containing distilled water and untreated stream water. One set of three flasks was kept static with occasional hand shaking and another set of three flasks was kept on a shaker. The experiment was conducted at two 
temperatures $\left(22 \cdot 2^{\circ} \mathrm{C}\right.$ and $\left.25^{\circ} \mathrm{C}\right)$. At $12,24,29$ and 48 hours, the percentage of exuviae sinking as well as plate counts of bacteria were recorded. This experiment was repeated five times.

e) Water quality: Methodology is similar to experiment (d), except that only untreated and aerated water from each stream was used. Flasks were incubated at $29^{\circ} \mathrm{C}$. At the time of field collections of $C$. riparius exuviae for this experiment, water chemistry data were collected for nitrate $\mathrm{N}_{3}$ ) and ammonia $\left(\mathrm{NH}_{4}\right)$ content using a Hach Ds-EH2 spectrophotometer. This experiment was repeated five times.

f) Aerobic and anaerobic decomposition: To assess aerobic decomposition, exuviae of $C$. riparius were heat-fixed on slides, by passing slides over a flame, and then immersed in bottles of aerated Mill Creek water. Anaerobic decomposition used fixed exuviae in Mill Creek water, but bottles were completely filled with no air space, closed airtight, and incubated at $20^{\circ} \mathrm{C}$. Anaerobic conditions were expected after two days due to high microbial numbers. For each treatment, two slides were removed daily for 10 days, stained, and observed for progression of decomposition using photomicrographs. To assess anaerobic conditions, the slides were examined after 10 days, then monthly for one year.

g) Waxes and proteins: Chironomus riparius exuviae were treated to remove waxes, or waxes and proteins. Wax was removed by refluxing with 100 $\mathrm{ml}$ of petroleum ether for 30 minutes over a water bath. Half of the dewaxed exuviae were then treated with $100 \mathrm{ml}$ of $10 \% \mathrm{~W} / \mathrm{V}$ aqueous solution of $\mathrm{NaOH}$ for three hours to achieve deproteinization. Treated exuviae were held in sterile beakers containing aerated Mill Creek water. The time taken for $100 \%$ of exuviae to sink was recorded.

\section{2) Succession of microorganisms colonizing exu- viae}

Exuviae of $C$. riparius collected from within the wooden channel were held in vials of Mill Creek water in the lab. Exuviae were picked from the water at various intervals from $2-72$ hours, washed in sterile water, and placed in tubes containing tryprose broth. Tubes were incubated at room temperature for 36 hours. The growth from tubes was then placed on Dextrose-Tryptone (DT) agar to isolate bacteria and Cook's Rose Bengal (CRB) agar to isolate fungi. DT plates were incubated for another 48 hours to record bacterial growth and CRB plates incubated for 7 days to record fungal growth. The relative growths of bacteria, actinomycetes and fungi from different ages of exuviae were recorded and curves for succession determined. Relative density values on a scale of 1-4 were assigned for colony growth on plates, with a value of 4 given to the plate with the greatest number of colonies and the rest given qualitatively lower numbers in comparison. Exuviae were also picked at different time intervals (between 2-72 hours) and stained to observe the progression of decomposition. These techniques were also used in experiment $(\mathrm{g})$ above, both in aerobic and anaerobic conditions.

\section{3) Isolation of exuviae-metabolizing bacteria}

Exuviae of $C$. riparius were rinsed to remove passive-adhering bacteria and detritus, and placed on a mineral agar medium devoid of a carbon source. Bacterial growths around the exuviae were isolated after incubation at $20^{\circ} \mathrm{C}$ for 36 hours. The colonies were pure-cultured on DT agar, and maintained on nutrient agar slants. A $2 \%$ chitin agar was prepared using crude crustacean chitin (commercial grade, Sigma Chemicals) and purified using the method described by Skujins et al. (1965). Bacteria were identified using tests described in Buchanan and Gibbons (1974).

\section{4) Isolation and identification of fungi growing on exuviae}

Exuviae from all four taxa were washed twice in sterile water with a $2 \%$ solution of streptomycin to inhibit bacterial growth, and then placed on plates with potato-dextrose agar both with and without added antibiotic. A second washing technique used a medium of $1.5 \%$ bactoagar. Plates were incubated at $25^{\circ} \mathrm{C}$ for 5-7 days for most fungi and up to two weeks for slow-growing fungi. Isolated fungi were maintained on pure cultures of potato-dextrose agar and streaked on plates of agar prepared with blended mixtures of exuviae. Two sterilized, blended mixtures were made from water, $1.5 \%$ bactoagar and either C. riparius from Mill Creek or a mix of the three taxa collected from Deer Creek. Fungi were identified by isolating growths, followed by slide-mounting and staining. Identification keys used were Coker (1923), Barnet and Barry (1972), Fuller (1978) and Alexopoulos and Mins (1979). Water molds isolated from water agar were baited with hemp seeds and transferred to YPSS-Emerson medium to induce spore production to assist with identifications.

\section{Results}

\section{Establishing baseline data}

One hundred percent of exuviae of D. nivoriunda, O. thienemanni and Eukiefferiella from Deer Creek sank within seven days in the control group 


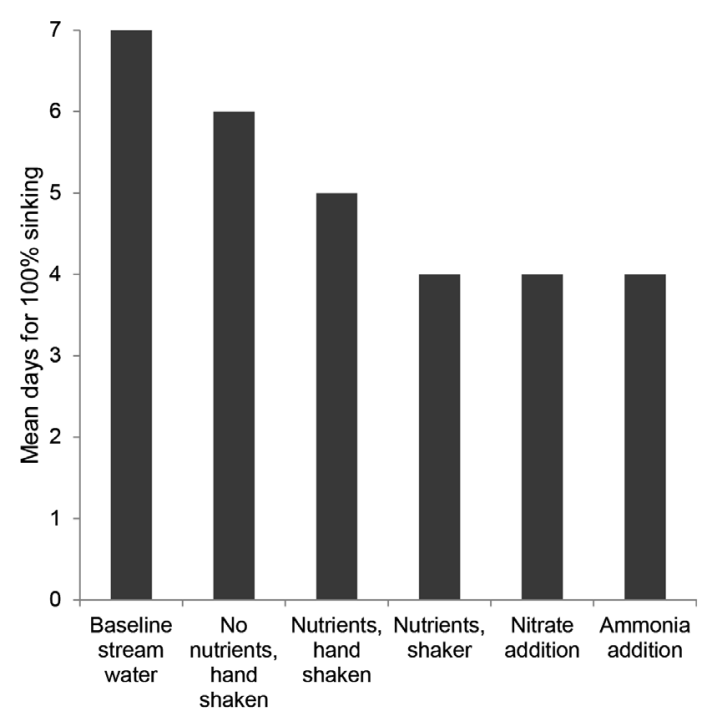

Figure 1. Mean D. nivoriunda, O. thienemanni, and Eukiefferiella exuviae sinking times across treatments, Deer Creek water, $20^{\circ} \mathrm{C}$.

(Fig. 1). Without separation into individual flasks, we cannot compare variation of baseline sinking rates for each species.

\section{Nutrients and shaking}

One hundred percent of $D$. nivoriunda, O. thienemanni and Eukiefferiella exuviae sank within four days when nutrient solution \#1 was added and flasks were kept on a shaker, while those receiving nutrient solution \#1 but held stationary sank within five days (Fig. 1). Control flasks with no added nutrients but occasional shaking by hand had 100\% sinking in six days. Photomicrographs revealed greater microbial colonization with increased nutrients or aeration via shaking.

\section{Nitrate-nitrogen vs. ammonia-nitrogen}

The percentage of Eukiefferiella that sank varied considerably when comparing Nitrate-N and Ammonia- $\mathrm{N}$ shaking treatments, however no difference in sinking rates was observed between these treatments when flasks were only occasionally hand shaken (Fig. 1, Table 1). Neither D. nivoriun$d a$ nor $O$. thienemanni differed notably in response to nutrient type, but $D$. nivoriunda sank much slower in shaker treatments. In nitrate treatments, it took an average of four days for all exuviae to sink, while $80-100 \%$ of exuviae sunk in ammonia treatments in the same time.

Temperature, microbial activity and mechanical shaking

All C. riparius exuviae sank within 48 hours and more than $50 \%$ of exuviae sank within 24 hours regardless of treatment (Table 2). All three factors appear to affect the rate of exuviae sinking, with faster sinking generally related to warmer water, presence of naturally-occurring microbes and consistent shaking.

\section{Water quality}

Proportion of $C$. riparius exuviae sinking is also influenced by water quality and corresponds to nutrients and bacterial numbers (Table 3). A large majority of exuviae sank within 12 hours in Mill Creek water with higher nutrients and bacterial counts, and all sank within 24 hours. Although nutrients were higher in Deer Creek water than Mud Creek, there were no substantive differences between bacterial counts or sinking rates.

Table 1. Average percentage of exuviae sinking in three days under nutrient and shaking treatments, using Deer Creek water at $20^{\circ} \mathrm{C}$.

\begin{tabular}{lccc}
\hline & Eukiefferiella sp. & O. thienemanni & D. nivoriunda \\
\hline Nitrate-N, shake & $90 \%$ & $30 \%$ & $10 \%$ \\
Ammonia-N, shake & $30 \%$ & $20 \%$ & $10 \%$ \\
Nitrate-N, no shake & $40 \%$ & $10 \%$ & $80 \%$ \\
Ammonia-N, no shake & $40 \%$ & $10 \%$ & $90 \%$ \\
\hline
\end{tabular}

Table 2. Percentage of $C$. riparius exuviae sinking in distilled water and Mill Creek water, averaged from five replicates.

\begin{tabular}{lcccccc}
\hline Time & \multicolumn{2}{c}{$22.2^{\circ} \mathrm{C}$ Shaken } & \multicolumn{2}{c}{$25^{\circ} \mathrm{C}$ Static } & \multicolumn{2}{c}{$25^{\circ} \mathrm{C}$ Shaken } \\
& Distilled & Stream & Distilled & Stream & Distilled & Stream \\
\hline $12 \mathrm{hrs}$ & 14 & 37 & 14 & 70 & 50 & 95 \\
$24 \mathrm{hrs}$ & 56 & 80 & 83 & 95 & 80 & 100 \\
$29 \mathrm{hrs}$ & 70 & 100 & 90 & 100 & 90 & \\
$48 \mathrm{hrs}$ & 100 & & 100 & & 100 & \\
\hline
\end{tabular}


Table 3. Effects of nutrients (nitrate and ammonia) and bacterial numbers on exuviae sinking rate.

\begin{tabular}{lccccc}
\hline & $\mathrm{NO}_{3}(\mathrm{mg} / \mathrm{L})$ & $\begin{array}{c}\mathrm{NH}_{4} \\
(\mathrm{mg} / \mathrm{L})\end{array}$ & $\begin{array}{c}\text { Bacteria } \\
(\text { no./mL })\end{array}$ & $\begin{array}{c}\text { Percent sinking, } \\
12 \text { hours }\end{array}$ & $\begin{array}{c}\text { Percent sinking, } \\
24 \text { hours }\end{array}$ \\
\hline Mill Creek & 0.488 & 0.666 & $2 \times 10^{4}$ & 70 & 100 \\
Deer Creek & 0.132 & 0.244 & $2 \times 10^{2}$ & 30 & 80 \\
Mud Creek & 0.066 & 0.183 & $2 \times 10^{2}$ & 40 & 80 \\
\hline
\end{tabular}

Aerobic and anaerobic decomposition

Under aerobic decomposition, components of $C$. riparius exuviae were detectable for up to 10 days. After 10 days, no discernable portions of exuviae remained on slides. All exuviae were initially colonized along the pleurites and conjunctives. The intersegmental conjunctives were the first to be metabolized, resulting in segments breaking apart. The cephalothorax was more resistant. Both rod and filamentous microbes dominated the aerobic decomposition process. Anaerobic experiments revealed that exuviae took up to a year to completely decompose. The sequence of colonization and degradation of pleurites and conjunctives was similar to the aerobic process.

\section{Waxes and proteins}

Dewaxed and deproteinized C. riparius exuviae sank faster (5 days for $100 \%$ sinking) than dewaxed exuviae ( 7 days for $100 \%$ sinking) in aerated stream water.

\section{Succession of microorganisms colonizing exuviae}

Qualitative results of succession showed a distinct transition from bacterial to fungal dominance over several days (Fig. 2). Dominance of bacteria appeared stable prior to 31 hours, while fungi were dominant after 49 hours and a distinct transition from bacterial dominance to fungal dominance occurred in-between.

\section{Isolation of exuviae-metabolizing bacteria}

Four different bacterial cultures were isolated and maintained on nutrient agar slants (Table 4), indicating that bacteria can utilize exuviae as a sole carbon source. There was no growth on water or mineral agar devoid of any carbon source. Bacteria species names are used tentatively since biochemical characteristics differed slightly from typical species and presumably represent different strains of each species. All four species were gram-negative aerobic rods capable of growth on chitin agar. For descriptions of each species cultured, see Kavanaugh (1988). Photographs of the progression of primarily bacterial decomposition are shown in Fig. 3. Decomposition was initially more pronounced in pleurite and conjunctive regions. Bacteria colonized and metabolized inner parts of the segments later. The cephalothorax was more resistant to metabolization than the abdomen.

Isolation and identification of fungi growing on exuviae

Eight genera of fungi were isolated from exuviae, all of which are common aquatic and airborne fungi (Table 4). Microscopic examination of exuviae

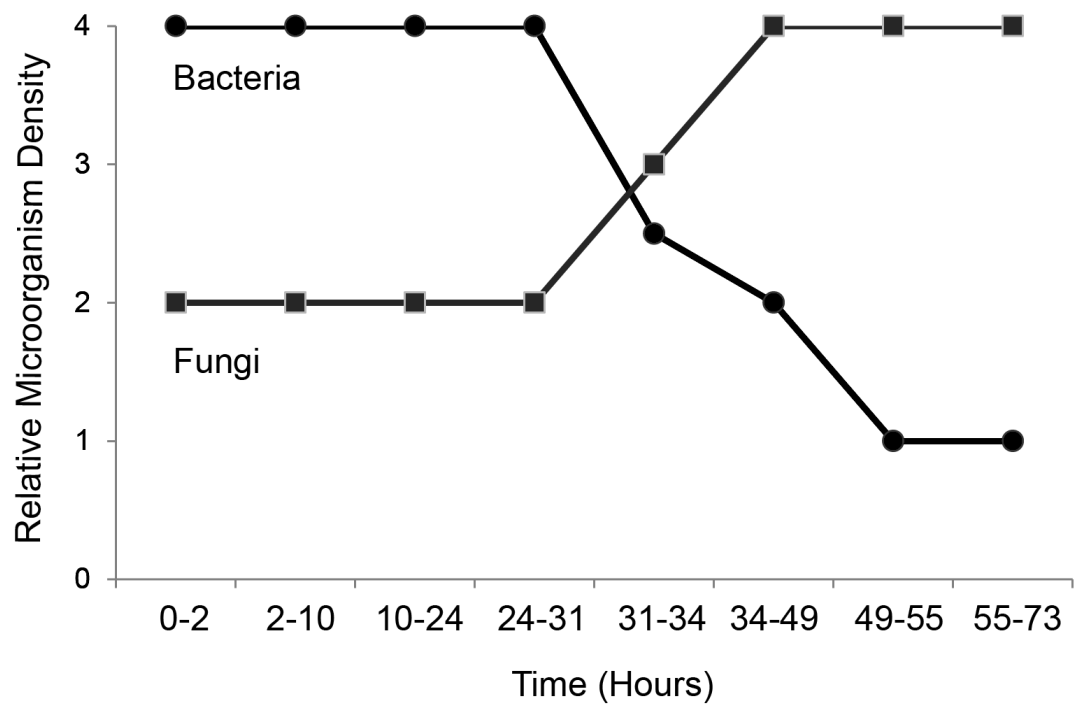

Figure 2. Succession of microbes on exuviae. Qualitatively ranked based on scores for colony growth on plates, with categories ranging from the greatest number of colonies (4) on a plate to the smallest (1). 

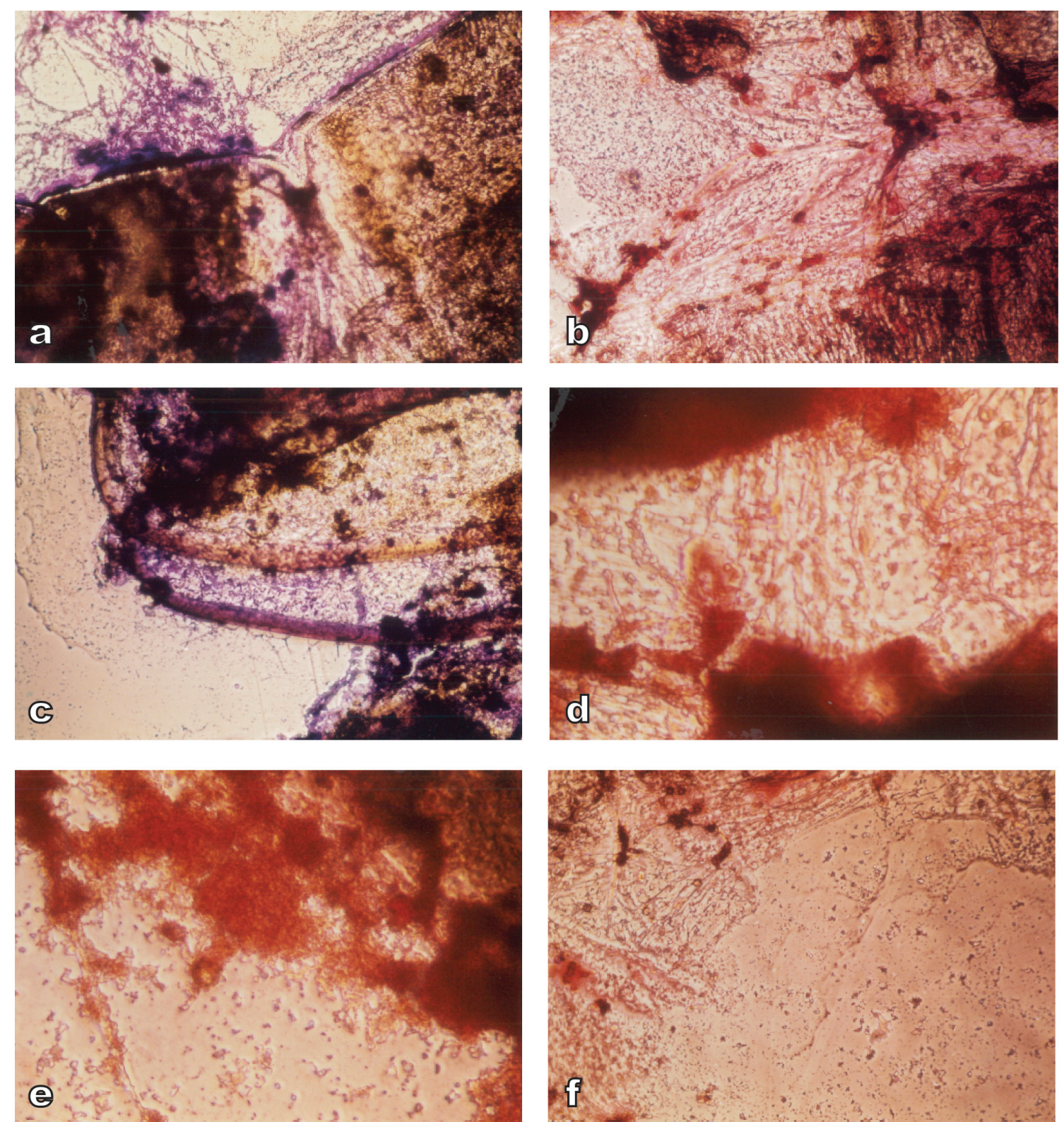

Figure 3. Progress of C. riparius exuviae decomposition over time. a) beginning of decomposition, with two abdominal segments and intersegment shown; b) intersegmental region with microbes (400x); c) cephalothorax showing more resistance than abdominal segments to decomposition (100x); d) intersegment decomposed, with bacteria along segment edges (400x); e) large numbers of metabolizing bacteria (400x); f) highly decomposed segment (100x).

showed that fungi were decomposing exuviae, though the antibiotic did not necessarily eliminate all bacterial processes. The cephalothorax was more resistant to decomposition than the abdominal region. During fungal growth, abdominal segments and conjunctive areas were solubilized at about the same rate, although abdominal setae remained undegraded throughout observations.

Water molds were isolated on exuviae of all taxa, but none sporulated and were therefore not identifiable. However, the dominant water mold resembled the genus Achlya, with numerous sporangia that were broad in the middle and narrower at the ends, usually extending from vegetative hyphae. Zoospores were encysted within and released from the sporangium. Vegetative hyphae had numerous gemme or irregular growth. Biflagellate secondary spores were also seen. In "Achlya", antheridia and oogonia were not seen.

\section{Discussion}

The main factor affecting the sinking of exuviae in the laboratory was microbial numbers as indicated by water quality and nutrient concentrations. Additional factors were temperature and mechanical disturbance following initial decomposition. A succession of microorganisms capable of metabo- 
Table 4. Bacteria and fungi colonizing chironomid pupal exuviae as a nutrient source.

\begin{tabular}{|c|c|c|c|}
\hline & & Chironomus riparius & $\begin{array}{l}\text { O. thienemanni } \\
\text { D. nivoriunda } \\
\text { Eukiefferiella sp. }\end{array}$ \\
\hline \multirow{4}{*}{ 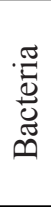 } & Flavobacterium sp. (aquatile?) & $X$ & $\mathrm{n} / \mathrm{a}$ \\
\hline & Pseudomonas sp. (alcaligenes?) & $\mathrm{X}$ & $\mathrm{n} / \mathrm{a}$ \\
\hline & Pseudomonas sp. (facilis?) & $\mathrm{X}$ & $\mathrm{n} / \mathrm{a}$ \\
\hline & Pseudomonas sp. (fluorescens?) & $\mathrm{X}$ & $\mathrm{n} / \mathrm{a}$ \\
\hline \multirow{8}{*}{$\begin{array}{l}\overrightarrow{60} \\
\equiv \\
\equiv\end{array}$} & Alternaria & $\mathrm{X}$ & $\mathrm{X}$ \\
\hline & Aspergillus & $\mathrm{X}$ & $\mathrm{X}$ \\
\hline & Cladosporium & $\mathrm{X}$ & $\mathrm{X}$ \\
\hline & Mucor & & $\mathrm{X}$ \\
\hline & Pestalotia & & $\mathrm{X}$ \\
\hline & Phoma & $\mathrm{X}$ & \\
\hline & Rhizopus & & $\mathrm{X}$ \\
\hline & Trichoderma & $\mathrm{X}$ & $\mathrm{X}$ \\
\hline
\end{tabular}

lizing exuviae as a source of carbon were isolated and identified. All exuviae sank within a range of 1-7 days, with rates depending on these factors. In a pristine creek without substantial nutrient additions or turbulence, exuviae collections may be expected to represent emergences from up to seven prior days. In contrast, streams with elevated water temperature, nutrients and agitation create conditions where exuviae may only represent emergences from the previous 12-48 hours.

Rate of sinking for each species was affected by both nutrients and mechanical disruption. Eukiefferiella had fast sinking rates in nitrate treatments with constant agitation. Diamesa nivoriunda had the opposite response to agitation, with stronger sinking rates in stable conditions. In contrast, $O$. thienemanni had no distinct response to either treatment. These differences illustrate how environmental conditions can influence the availability and abundance of floating exuviae across genera. Although baseline results showed that all species sank within seven days, they were not run concurrently to nutrient and shaking experiments and thus cannot act as a control.

Separate experiments using C. riparius also indicated a heightened sinking response to increased temperature, nutrients and agitation. While rates of sinking were faster than the other three genera, C. riparius exuviae were exposed in situ to higher nutrients and microbes since Mill Creek receives sewage effluent. This water was used in all $C$. riparius experiments, while experiments on Deer Creek genera used water with distinctly lower bacterial counts. No direct comparisons of sinking rates were made under the same nutrient and microbial conditions for all four genera, but we suspect that Eukiefferiella, Diamesa and Orthocladius would all sink faster in Mill Creek or other enriched waters. Under nutrient-enriched conditions, particularly if turbulence is increasing aeration and helping to weaken exuviae at conjunctives, a maximum of 3-4 days can be expected until most specimens have sunk.

While exuviae can be used effectively to classify waterbodies based on nutrient levels (Ruse 2010), nutrient levels and type (i.e., nitrate vs. ammonia) can conversely influence floating times and thus detectability of taxa. Organic content of water has been shown to be influential to chitinoclasts, with greater abundances in polluted waters (Hood and Meyers 1973), which may influence the colonization rates and subsequent proliferation of bacterial growth on recently shed exuviae. Therefore, sinking rates for taxa are important to consider during study design. Additional experimental testing, using simple methods such as those in the current study, would help determine sinking rates for indicator species of healthy or impaired conditions.

Under laboratory conditions, sinking was more influenced by temperature than mechanical disruption. This indicates that increased microbial activity due to associated temperature is more important than agitation. However, our conclusions may not extrapolate well to natural systems with greater wave action and energy or shear forces. The numbers and activity of chitinoclastic microbes have been shown to be a function of temperature, with a common optimal temperature of $30^{\circ} \mathrm{C}$ but a range of activity between $0-40^{\circ} \mathrm{C}$ (Hood and Meyers 1973). As a result, sampling for exuviae should 
take into account water temperatures to estimate the timeframe that collections represent. Annual or seasonal data collection with temperature loggers may help reveal how ecological and temperature patterns coincide (Egan 2014).

Coffman (1973) believed that waxes kept exuviae unwettable and resistant to sinking until microbial metabolism removed wax. In the present study, waxes appeared crucial for initial colonization and microbial metabolism because in the absence of waxes, the initiation of metabolism was delayed. Sinking rates were faster for untreated, waxy exuviae than for dewaxed exuviae. In contrast, the faster sinking of dewaxed and deproteinized exuviae, which lead to a disruption of structural integrity, probably mimicked a later stage of decomposition. The progression of decomposition was the same in both aerobic and anaerobic conditions, although it was extended greatly in the absence of oxygen.

Bacteria were dominant early colonizers and began the process of metabolizing exuviae. The conjunctive abdominal regions were solubilized faster, leading to inter-segmental separation. The cephalothorax was resistant and only solubilized after long incubation. The current findings revealed a more truncated pattern of microbial succession of chitinoclasts than observed by Aumen (1980). In his study, bacteria were initial colonizers, fungi dominated over time, yet bacteria regained dominance in the final stages of decomposition. Although the isolated cultures showed growth on chitin media, they might have been involved in metabolizing any of the components of exuviae including chitin. Coffman (1973) suggested that bacteria initially colonize exuviae on the surface of water and only after sinking and contact with substrate did fungal colonization occur.

Microscopic examination revealed fungi utilizing exuviae as a nutrient source and contributing to decomposition. Four fungal genera colonized chironomid exuviae of all species, while four other fungi differed between the Deer Creek chironomids and $C$. riparius from Mill Creek. It is possible that all fungi colonizing exuviae were airborne and settled on floating pupae. As with bacteria, the cephalothorax and abdominal setae were more resistant to decomposition. Fungi belonging to Saprolegniaceae are known to colonize insect exuviae, including Chironomidae (Dick 1970). In living insects, fungal pathogens attack the cuticle of specific hosts using particular enzymes (Bye and Charnley 2008); these fungal enzymes are used in biocontrol efforts and it would be useful to de- termine if similar enzymes are responsible for the rapid breakdown at abdominal conjunctives.

Variation in genus- or species-level responses of exuviae to sinking is important to consider. Degree of chitinization was noted by Coffman (1973), where lightly chitinized and fragile Procladius exuviae had a faster breakdown rate. In contrast, he found Chironomus plumosus-type exuviae took one week to break down and Cryptochironomus exuviae were still intact after a month. Current results show that decomposition was faster at conjuctives, suggesting that lightly chitinized exuviae should sink faster, particularly with increased physical disturbance. However, in the experience of the authors, while slide mounting exuviae there are some species that break easily at conjunctives and others that tend to break across segments. We believe this indicates that a subjective measurement of chitinization (e.g., dark and heavy sclerotization) may not be a good indicator of likelihood of sinking since weak points, such as the cephalothorax-abdomen junction, could decompose quickly and cause rapid sinking.

\section{Conclusions}

Microbial numbers, temperature, nutrients and mechanical disruption were all found to be influential and interacting factors in the sinking of surface floating pupal exuviae. Microbial metabolism began to break down exuviae at intersegmental conjunctive joints so that mechanical agitation caused them to break apart and sink. Exuviae were readily metabolized by bacteria, actinomycetes, and fungi. Bacteria dominated initial metabolism and fungi dominated later. In waters with considerable organic nutrient content, exuviae can be expected to sink within $1-2$ days at $22^{\circ} \mathrm{C}$ or higher water temperatures. In low-nutrient streams at similar temperatures, some exuviae may float for up to a week. While environmental factors play vital roles in decomposition and sinking of pupal exuviae, standard techniques (e.g., Ferrington et al. 1991, Wilson and Ruse 2005) are likely influenced by generic-level decomposition responses. As a result, researchers using pupal exuviae must consider environmental conditions that influence availability of different species for detection or relative abundances of specimens collected.

\section{References}

Alexopoulos, C. J. and C. W. Mins. 1979. Introductory Mycology, $3^{\text {rd }}$ edition. John Wiley. New York. 632 pp.

Anderson, S. O. 1979. Biochemistry of insect cuticle. - Annual Review of Entomology 24: 29-61. 
Aumen, N. G. 1980. Microbial succession on a chitinous substrate in a woodland stream. $-M i$ crobial Ecology 6: 317-327.

Barnet, H. L. and B. H. Barry. 1972. Illustrated Genera of Imperfect Fungi, $3^{\text {rd }}$ edition. Burgess Publishing Co. 241 pp.

Bouchard, R. W., Jr. and L. C. Ferrington, Jr. 2011. The effects of subsampling and sampling frequency on the use of surface-floating pupal exuviae to measure Chironomidae (Diptera) communities in wadeable temperate streams. - Environmental Monitoring and Assessment 181: 205-223.

Buchanan, R. E. and N. E. Gibbons. 1974. Bergey's Manual of Determinative Bacteriology, $8^{\text {th }}$ edition. The Williams \& Wilkins Company. $1268 \mathrm{pp}$.

Bye, N. J. and A. K. Charnley. 2008. Regulation of cuticle-degrading subtilisin proteases from the entomopathogenic fungi, Lecanicillium spp.: implications for host specificity. - Archives of Microbiology 189: 81-92.

Coffman, W. P. 1973. Energy flow in a woodland stream ecosystem II. The taxonomic composition and phenology of Chironomidae as determined by the collection of pupal exuviae. $-A r$ chiv für Hydrobiologie 71: 281-322.

Coker, W. C. 1923. Saprolegniaceae. University of North Carolina Press. 201 pp.

Dick, M. W. 1970. Saprolegniaceae on insect exuviae. - Transactions of the British Mycological Society 55: 449-458.

Egan, A. 2014. Communities in freshwater coastal rock pools of Lake Superior, with a focus on Chironomidae (Diptera). Ph.D. dissertation, University of Minnesota.

Ferrington, L. C., Jr., W. P. Coffman and M. B. Berg. 2008. Chironomidae. In, R. W. Merritt, K. W. Cummins and M. B. Berg (editors). An Introduction to the Aquatic Insects of North America. Kendall/Hunt Publishing Co., Dubuque, IA. 1214 pp.

Ferrington, L. C., Jr., M. A. Blackwood, C. A. Wright, N. H. Crisp, J. L. Kavanaugh and F. J. Schmidt. 1991. A protocol for using surfacefloating pupal exuviae of Chironomidae for rapid bioassessment of changing water quality.
Proceedings of the Vienna Symposium, IAHS Publication 203.

Fuller, M. A. 1978. Lower Fungi in the Laboratory. University of Georgia. $213 \mathrm{pp}$.

Hood, M. A. and S. P. Myers. 1973. The biology of aquatic chitinoclastic activities. - Bulletin de la Societe Franco Japonaise d'Oceanographie 11: 1-17.

Kavanaugh, R. G. 1988. Decomposition studies of Chironomidae pupal exuviae (Chironomidae: Diptera). M.A. thesis, University of Kansas.

Langton, P. H. 1991. A Key to Pupal Exuviae of West Palearctic Chironomidae. P. H. Langton, Huntington, Cambridgeshire, England. 386 pp.

Nation, J. L. 2008. Insect Physiology and Biochemistry, $2^{\text {nd }}$ edition. CRC Press, Boca Raton, FL. 544 pp.

Raunio, J. and T. Muotka. 2005. The use of chironomid pupal exuviae in river biomonitoring: the importance of sampling strategy. - Archiv für Hydrobiologie 164: 529-545.

Raunio, J., L. Paasivirta and H. Hämäläinen. 2010. Assessing lake trophic status using springemerging chironomid pupal exuviae. - Fundamental and Applied Limnology 176: 61-73.

Ruse, L. 2010. Classification of nutrient impact on lakes using the chironomid pupal exuvial technique. - Ecological Indicators 10: 594-601.

Skujins, J. J., H. J. Potgieter and M. Alexander. 1965. Dissolution of cell walls by a streptomycete chitinase and B-(1-3) glucanase. - Archives of Biochemistry and Biophysics 111: 358-364.

Tracy, S. F and J. R. Vallentyne. 1968. Fungal decomposition of Mysis relicta. - Transactions of the British Mycological Society 30: 352-356.

Warner, C. E. and C. I. Randles. 1977. Preliminary studies on chitin decomposition in Lake Erie sediments. - Ohio Journal of Science 5: 224230.

Wilson, R. S. and L. P. Ruse. 2005. A guide to the identification of genera of chironomid pupal exuviae occurring in Britain and Ireland and their use in monitoring lotic and lentic fresh waters. - Freshwater Biological Association Special Publication 13, Cumbria, UK. 